\title{
Bryophyte and lichen diversity: A comparative study
}

\author{
EMMA J. PHARO AND ANDREW J. BEATTIE \\ School of Biological Sciences, Macquarie University, North Ryde, NSW 2109, \\ Australia
}

\begin{abstract}
We describe the regional species richness, variation in species richness and species turnover of bryophytes and lichens from 36 sites in lowland forests of southeastern Australia. The analyses subdivided the two major taxa into their constituent sub-groups: mosses, liverworts, and crustose, fruticose and foliose lichens. They also explored correlations between selected environmental variables and patterns of diversity. On a regional scale, there were 77 species of bryophytes and 69 species of lichens, giving a total of approximately one-third of the total number of vascular plant species in the region. Mean species richness was higher for lichens than bryophytes. Also, the two taxa were negatively correlated because lichens favoured dry sites and bryophytes favoured moist ones. Species turnover was greater for bryophytes than lichens, largely due to the distribution of liverwort species. Foliose lichens showed higher levels of turnover than crustose lichens. Multiple regression and canonical correspondence analysis showed that both taxa and all sub-groups responded to the same three variables: vascular plant cover, time since last fire and topographic position. Other variables, including time since logging and intensity of logging, explained little variation in bryophyte or lichen diversity. The data suggest that the strategies for the conservation of bryophyte and lichen biodiversity will be different, to reflect the different patterns of species richness and species turnover.
\end{abstract}

Key words: alpha diversity, beta diversity, bryophyte, fire, lichen.

\section{INTRODUCTION}

Bryophytes and lichens are important components of biodiversity. Their species richness may be equal to or greater than that of vascular plants at given sites (Slack 1977; Brown et al. 1994; Jarman \& Kantvilas 1994). However, studies of their diversity remain scarce and mostly focused on moist habitats, particularly in the northern hemisphere, and few address lichen diversity or dry habitats (Slack 1977; Lee \& La Roi 1979; Söderström 1981; Stark \& Castetter 1987; Gradstein et al. 1989; Wolf 1994; Jarman \& Kantvilas 1995; Vitt et al. 1995).

Bryophytes and lichens are often lumped together as 'lower' plants, but we anticipated that because of the differences in their physiology and structure they would exhibit different patterns of diversity. Further, the bryophytes consist of two rather dissimilar groups, the mosses and the liverworts, and the lichens exhibit a wide variety of life forms, being crustose, fruticose or foliose. Consequently, we were also interested in differences in patterns of diversity among these entities.

This is the first large-scale study to describe regional species richness, and to address its constituent patterns of species richness ( $\alpha$-diversity) and species turnover ( $\beta$-diversity), for both bryophytes and lichens. The aim

Accepted for publication September 1996. was to compare bryophyte and lichen diversity in a variety of forest types, ranging from dry sclerophyll to riparian, and to relate patterns of diversity to a variety of habitat variables. We explored three hypotheses: (i) bryophyte and lichen species richness is the same and responds to the same habitat variables; (ii) the rate of species turnover for bryophytes and lichens is the same and responds to the same habitat variables; and (iii) species richness and turnover among the major subgroups (i.e. mosses, liverworts, and crustose, foliose and fruticose lichens) are the same and respond to the same habitat variables. These hypotheses were designed to reveal whether or not these organisms were indeed a relatively uniform group. Different patterns of diversity and different responses to habitat variables would suggest different strategies for their conservation.

\section{METHODS}

\section{Study sites}

Thirty-six 0.1 ha sites established by State Forests of NSW for an Environmental Impact Assessment (EIA), between 70 and $130 \mathrm{~km}$ north of Sydney in the Morisett Area, were used (State Forests of New South Wales 1995). The sites ranged from open forest with a grassy understorey to more sheltered wet sclerophyll 
forest with a rainforest understorey. Four sites were adjacent to creeks and are referred to as riparian. Thirty-four sites were on Narrabeen sandstone and two were on Permian coal measures. Average daily maximum temperatures for the area ranged from $15^{\circ} \mathrm{C}$ in July to $27^{\circ} \mathrm{C}$ in January and annual rainfall ranged from $1200 \mathrm{~mm}$ to $1400 \mathrm{~mm}$ (Forestry Commission of NSW 1984). Rainfall is seasonal with more than twice as much rain falling in summer than in winter.

\section{Environmental variables}

Nine environmental variables were recorded at each site. The first four quantified disturbance: time since logging, time since last fire, intensity of logging and intensity of last fire. Information on logging and fire were obtained from management records and field estimation (Binns 1996). Time since logging ranged from 4 to 50 years. Eight unlogged sites were included. Time since fire ranged from 1 to 50 years. For one site there was no evidence or record of fire and it was referred to as unburned. The unlogged and 'unburned' sites were given the value of 80 years since logging/fire and trials showed that values of 50,80 or 100 years made no significant difference to the results. No distinction was made between wildfire and controlled burns. The intensity of the last fire and logging events was assessed as either light ( $<30 \%$ canopy removal), moderate (30-60\% canopy removal) or severe $(60-70 \%$ canopy removal, rarely more; Binns, pers. comm. 1996).

The remaining five site factors were altitude, aspect, slope, topographic position and vascular plant cover. Altitude ranged between 30 and $530 \mathrm{~m}$ a.s.l. Aspect was coded into five groups $(1=$ north, $2=$ northeast or northwest, 3 = east or west, $4=$ southeast or southwest, $5=$ south). This approach avoided the problem that north is both $0^{\circ}$ and $360^{\circ}$ if compass bearings are used, and assumed that the greatest differences were between north and south (Söderström 1981). Slope was measured in degrees from the horizontal. Topographic position ranged from upper slopes, as there were no summit or ridge-top sites, to the sites beside creeks $(1=$ upper slope, $2=$ mid slope, $3=$ lower slope, $4=$ valley; Binns 1996). Percentage cover of vascular plants was calculated as follows: up to four vascular plant strata were identified (1-6 m, $6.1-20 \mathrm{~m}, 20.1-35 \mathrm{~m}$, over $35 \mathrm{~m}$ ), the percentage of the site covered by each stratum was estimated $(0-100 \%)$ and the percentage cover of all strata were summed (Binns 1996). Soil depth and soil type were also recorded but not included in the analysis as all sites were on deep, loamy soils.

\section{Sampling and identification}

Different substrates often support different assemblages of bryophytes and lichens (Nagano 1969; Brodo 1973; Söderström 1993); consequently, in each $50 \times 20 \mathrm{~m}$ site, sampling was stratified by substrate (ground, logs, rocks, tree trunks and fallen branches). Five quadrats on each substrate type were used, each randomly located. A $20 \times 20 \mathrm{~cm}$ quadrat with 10 vertical and 10 horizontal crosswires was used on the logs, rocks and bases of tree trunks. Relative abundance of each species was recorded as the number of times a species was directly beneath a crosswire. A pilot study showed that a $1 \times 1 \mathrm{~m}$ quadrat was necessary to sample the sparsely distributed bryophytes and lichens on the ground and on fallen branches. Bryophytes and lichens on tree trunks more than $10 \mathrm{~cm}$ in diameter were sampled at $50 \mathrm{~cm}$ from the ground. Only one $20 \times 20 \mathrm{~cm}$ quadrat was used per tree, regardless of the diameter of the tree. For the purposes of this study, data from the 25 quadrats ( 5 substrates $\times 5$ quadrats per substrate) were pooled to give species abundance per site. The effect of substrate will be examined in a separate paper.

All three classes of bryophytes, Musci (mosses), Hepaticae (liverworts) and Anthocerotae (hornworts), and the three life-forms of lichens (crustose, foliose and fruticose), were identified to species level with the exception of immature Lepidoziaceae, some specimens of Bryum and Barbula, immature Usnea spp. and some crustose lichens. Nomenclature followed Streimann and Curnow (1989) for mosses, Scott and Bradshaw (1986) for liverworts and hornworts, and McCarthy (1991) for lichens.

\section{Data analysis}

Bryophytes, lichens and their different sub-groups were analysed separately. The few fruticose lichens found were grouped with the foliose lichens and a single hornwort species was grouped with the liverworts.

Species richness or $\alpha$-diversity was calculated as number of species present at a site (Whittaker 1977). Variation in species richness attributable to the environmental variables was determined using simple and stepwise multiple regression (SPSS, release 6.0, 1983). Two variables with skewed distributions, slope and time since fire, were log transformed to satisfy normality requirements. Co-linearity of environmental variables was checked using variance inflation factors (VIF) and all values were below 1.28 (Sokal \& Rohlf 1995).

Two measures of the rate of species turnover were used: (i) gradient length of the first axis of detrended correspondence analysis (DCA); and (ii) the number of clusters formed at three arbitrary levels of dissimilarity $(0.8,0.7$ and 0.6$)$. Gradient length is the mean standard deviation of species turnover (Eilertsen $e t$ al. 1990). Presence/absence data was used because Eilertsen et al. (1990) showed that differences in the abundance scale could affect gradient length. Averagelinking clustering (UPGMA, using PATN; Belbin 1991a,b) was performed using the Bray-Curtis association measure and groups were identified using dendrograms. Liverworts were present in only 25 of the sites 
and consequently rates of turnover for the bryophyte groups were assessed across these sites only. Foliose lichens were absent from one site and rate of turnover was assessed across 35 sites.

Patterns of species turnover were examined using ordination diagrams produced by hybrid multidimensional scaling (Faith et al. 1987; using DECODA, Minchin 1991; 25 random starts, cut value $=0.8$, otherwise default parameters used). The distance between sites on the ordination diagram represents their compositional dissimilarity. The further sites are apart, the greater the dissimilarity and the higher the species turnover. Bryophyte and lichen association matrices were compared using Pearson's product moment correlation coefficient $(r)$ and significance levels were determined by Mantel tests (Sokal \& Rohlf 1995).

Environmental variables were related to the pattern of species turnover using the direct gradient approach of canonical correspondence analysis (CCA; ter Braak \& Prentice 1988; Jongman et al. 1995; using CANOCO, version 3.10, ter Braak 1991; all options followed the default settings unless otherwise stated). The advantage of CCA over other methods is that it partitions variation explained by each variable and constructs a model of significant variables (forward selection of variables option). Once a variable is added to the model, the fit and significance of the remaining variables is reassessed. The significance of the environmental variables was tested using a Monte Carlo approach with 999 permutations ( $\alpha=0.05$; Sokal \& Rohlf 1995). The variation in species scores explained by the environmental variables was shown by the eigenvalues.

\section{RESULTS}

\section{Regional species richness}

The total numbers of bryophytes and lichens were similar, with a total of 77 bryophytes and 69 lichens across the 36 sites (see Appendix I). Of the 77 bryophyte species, there were 56 mosses, 20 liverworts and one hornwort. There were 30 crustose, 36 foliose and three fruticose lichen species. There were two new records for NSW: a crustose lichen, Byssoloma subdiscoidans, and a tropical moss, Syrrhopodon armatus.

\section{Species richness}

\section{Bryophytes and lichens}

The species richnesses of bryophytes and lichens were negatively correlated ( $r=-0.345, P<0.05)$, with few bryophyte species and many lichen species found in the dry sclerophyll sites, but riparian sites being bryophyterich and lichen-poor. The contribution to the regional total of bryophytes from riparian forest was disproportionately high given only four of these sites were sampled. Fifty-four per cent of all bryophyte species were found in the four riparian sites, with 18 species unique to them. The range of species richness was very similar for bryophytes and lichens (1-28 and 4-26 species, respectively). However, mean species richness was much lower for bryophytes (mean $=9.2$, $\mathrm{SE}=1.0$ ) than lichens (mean $=15.5, \mathrm{SE}=1.0$ ).

\section{Mosses, liverworts, crustose and foliose lichens}

Within the bryophytes, liverwort species richness was lower than moss species richness (liverworts: range $0-10$, mean $=2.3, \mathrm{SE}=0.4$; mosses: range $1-18$, mean $=6.9, S E=0.7$ ). Seventy per cent of all liverwort species were found in the four riparian sites with six species not found in other forest types. There was very little difference in range and mean between the two groups of lichens (crustose: range $2-15$, mean $=7.7$, $\mathrm{SE}=0.6$; foliose: range $0-13$, mean $=7.51, \mathrm{SE}=0.6$ ).

\section{Environmental correlates}

Regressions of species richness of bryophytes, lichens and their sub-groups against environmental correlates

Table 1. Simple regression $\left(r^{2}\right)$ of bryophyte and lichen species richness on environmental variables

\begin{tabular}{|c|c|c|c|c|c|c|}
\hline & All & $\begin{array}{l}\text { Bryophyte } \\
\text { Moss }\end{array}$ & Liverwort & All & $\begin{array}{l}\text { Lichen } \\
\text { Crustose }\end{array}$ & Foliose \\
\hline Vascular plant cover & $0.30^{\star \star \star} 3$ & $0.21^{\star \star} 2$ & $0.33^{\star \star \star} 3$ & $0.40^{\star \star \star} 1$ & $0.16^{\star}$ & $0.38^{\star \star \star} 1$ \\
\hline Topographic position & $0.51^{\star \star \star} 1$ & $0.31^{\star \star} 1$ & $0.65^{\star \star \star} 1$ & $0.17^{\star} \quad 2$ & 0.02 & $0.18^{\star} \quad 3$ \\
\hline Time since fire $(\log )$ & $0.31^{\star \star \star} 2$ & $0.18^{\star \star 3}$ & $0.42^{\star \star \star} 2$ & $0.14^{\star} \quad 3$ & 0.03 & $0.24^{\star \star} 2$ \\
\hline Fire intensity ${ }^{\dagger}$ & 0.05 & 0.04 & 0.05 & 0.00 & 0.01 & 0.01 \\
\hline Time since logging ${ }^{\ddagger}$ & 0.04 & 0.05 & 0.02 & 0.01 & 0.00 & 0.01 \\
\hline Logging intensity & 0.02 & 0.03 & 0.00 & 0.06 & 0.03 & 0.04 \\
\hline Altitude & 0.04 & 0.03 & 0.05 & 0.00 & 0.00 & 0.01 \\
\hline Aspect & 0.04 & 0.09 & 0.02 & 0.05 & 0.04 & 0.07 \\
\hline Slope (log) & 0.03 & 0.05 & 0.00 & 0.02 & 0.02 & 0.10 \\
\hline
\end{tabular}

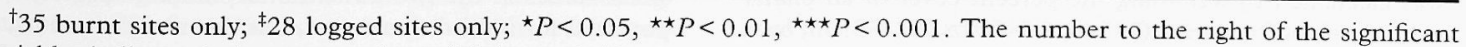
variables indicates its importance in explaining variation. 
are shown in Table 1 . The three variables, vascular plant cover (Fig. 1), topographic position and time since fire, explained significant amounts of the variation in both bryophyte and lichen species richness, with the latter two being much stronger for bryophytes than lichens. Lichen species richness was best explained by vascular plant cover alone as no other variable contributed a significant amount of variation when included in the multiple regression. Bryophyte species richness was best explained by vascular plant cover and topographic position $\left(R^{2}=0.58\right.$, d.f. $\left.=35, F=23.0, P<0.001\right)$.

The same three variables (vascular plant cover, topo-

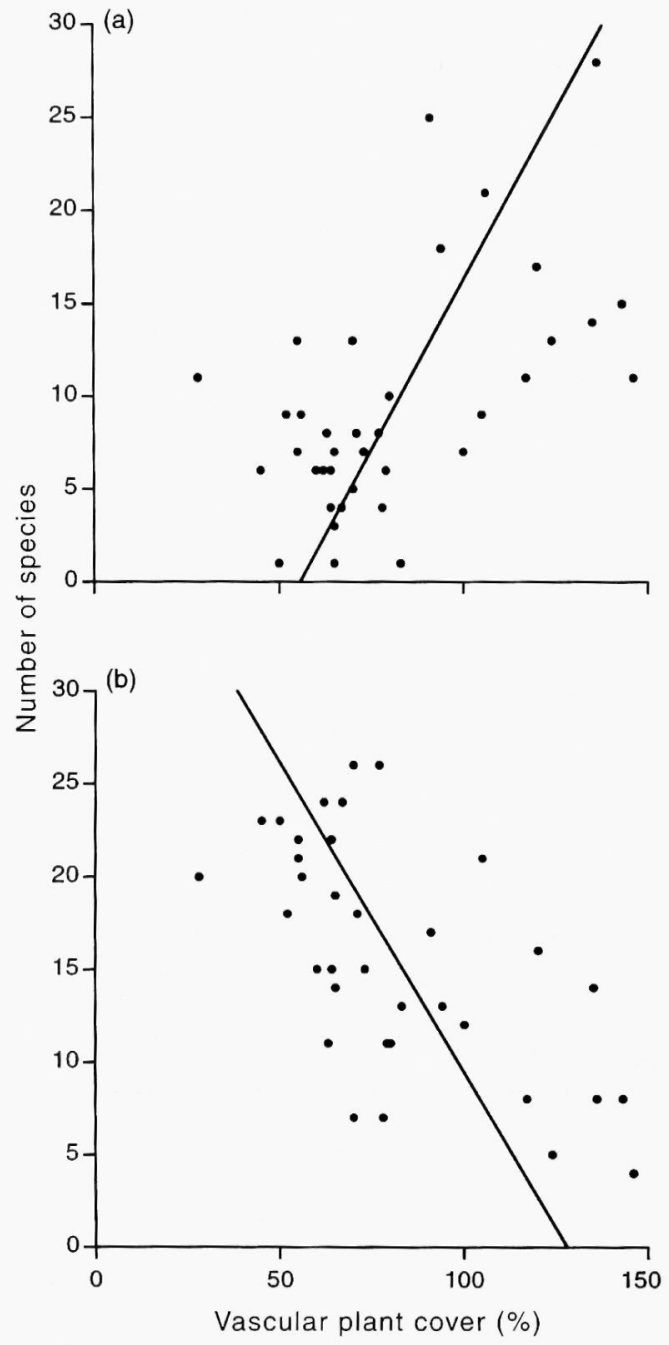

Fig. 1. Simple regression of species richness with vascular plant cover (a) bryophyte $\left(r^{2}=0.30, P<0.001\right.$, $y=2.722 x+55.747)$ and (b) lichen $\left(r^{2}=0.40, P<0.001\right.$, $y=-2.993 x+128.164)$. Percent cover of vascular plants was calculated by summing the percent cover of all plants within each of four strata $(1-6 \mathrm{~m}, 6.1-20 \mathrm{~m}, 20.1-35 \mathrm{~m}$, over $35 \mathrm{~m}$ ). Dense, overlapping vegetation can exceed $100 \%$. graphic position and time since fire) were significant in simple regressions with moss and liverwort species richness. More of the variation in liverwort species richness was explained compared to mosses. The optimal multiple regression for both moss and liverwort species richness included topographic position and time since fire (moss: $R^{2}=0.34$, d.f. $=35, F=8.5, P<0.001$; liver-

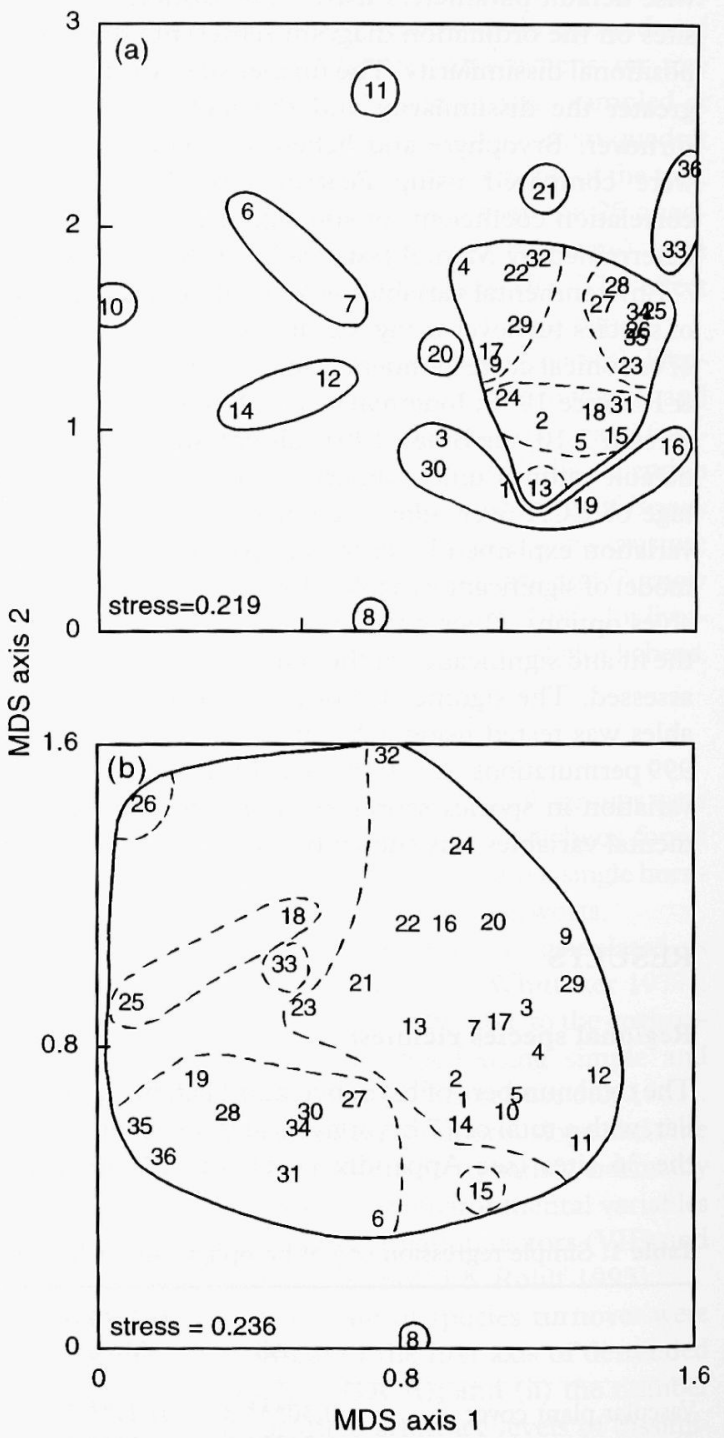

Fig. 2. HMDS ordination diagrams for (a) bryophytes (stress $=0.219)$ and (b) lichens (stress $=0.236$ ) with clusters superimposed. Numbers refer to sites and in general, the lower the number, the drier and more open the site. 0.7 level of dissimilarity represented by the solid line (-) and 0.6 level by the dashed line $(---)$. The 0.6 level $=$ dissimilarities 0.6 or less. Note the larger scale of the bryophyte plot. (The high stress values in the two-dimensional solution suggested the potential for a third dimension, but this analysis yielded no further information). 
wort: $R^{2}=0.757$, d.f. $=35, F=47.2, P<0.001$ ). Variation in crustose lichen species richness was best explained by vascular plant cover alone. This variable was also the best predictor of foliose lichen species richness as neither topographic position nor time since fire contributed significantly in a multiple regression (Table 1).

Some variables explained little variation in species
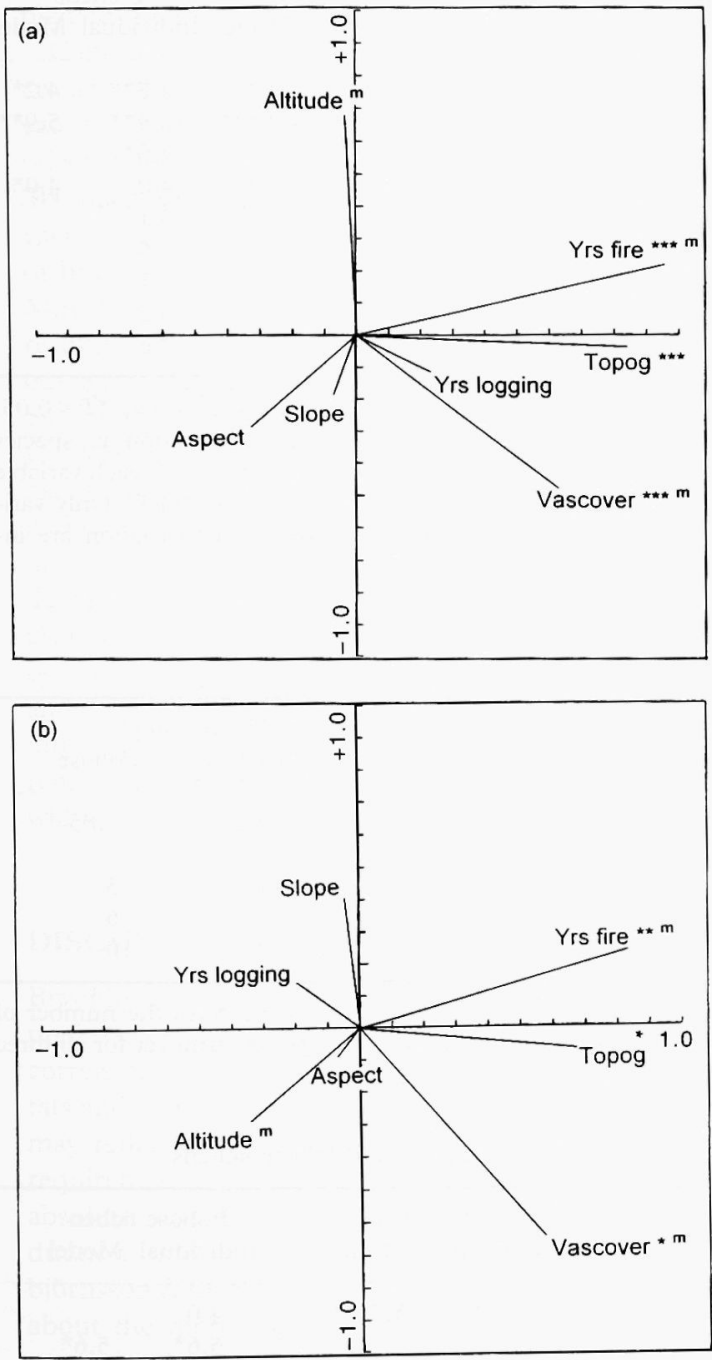

Fig. 3. Factor ordination of environmental variables for (a) bryophytes and (b) lichens. Variables explaining significant variance indicated: ${ }^{\star \star \star} P<0.001,{ }^{\star \star} P<0.01,{ }^{\star} P<0.05$ and $\mathrm{m}=$ included in CCA model. CCA axes 1 and 2 are shown. Length of the arrows represents the strength of the correlation with the species data; the more acute the angle between environmental variables, the higher the correlation. Topog = topographic position; Yrs logging = time since logging (years); Yrs fire = time since fire (years); Vascover $=$ vascular plant cover. richness of bryophytes, lichens or their sub-groups, most notably, time since logging and logging intensity. Fire intensity, altitude, aspect and slope were also of little importance.

\section{Species turnover}

\section{Bryophytes and lichens}

The rate of species turnover was much higher for bryophytes than lichens. The length of the first DCA gradient for bryophytes (4.78) was twice that for lichens (2.32). The sites have more lichen species in common than bryophytes, which results in lower dissimilarity between sites and fewer clusters. At each level of dissimilarity less than half the number of clusters was produced for lichens compared to bryophytes. At the $0.8,0.7$ and 0.6 levels of dissimilarity, there were 6,10 and 15 bryophyte clusters, and 0,2 and 7 lichen clusters (Fig. 2).

Correlations of pairwise dissimilarities indicated that patterns of species turnover for bryophytes and lichens were weak but significant $(r=0.15, P<0.001)$. Common elements in the ordination space include the separation of a particularly exposed and dry site (8) and a group of moister sites (site numbers greater than 24; Fig. 2). The correlation was even weaker without site 8 , although it was still significant $(r=0.089$, $P<0.05)$.

\section{Mosses, liverworts, crustose and foliose lichens}

Liverworts had a higher species turnover than mosses, as shown by the higher mean standard deviation or gradient length along the first DCA axis and the greater number of clusters at given levels of dissimilarity (Table 2). Foliose lichens had a higher species turnover than crustose lichens.

\section{Environmental correlates}

Vascular plant cover, time since last fire and topographic position were significantly correlated with variation in bryophyte and lichen species turnover (Table 3). All three variables were strongly correlated with the first CCA axis (Fig. 3). Altitude alone explained a significant proportion of variation in bryophyte and lichen species turnover once time since fire and vascular plant cover were removed. Altitude was highly correlated with the second CCA axis for both bryophyte classes. Eigenvalues or maximized dispersion of the species scores along the axes were much higher for bryophytes than lichens (bryophytes: axis $1=0.511$, axis $2=0.249$; lichens: axis $1=0.204$, axis $2=0.152$ ). Time since logging, logging intensity, aspect and slope did not explain a significant amount of species turnover for either bryophytes or lichens.

The three environmental variables, time since fire, topographic position and vascular plant cover, that 
explained variation in moss species turnover were the same as for bryophytes as a group (Table 4). This is not surprising because mosses comprised $74 \%$ of the bryophytes found. With respect to liverwort species turnover, vascular plant cover explained a significant amount of variation. The additional variables, time since fire, topographic position and fire intensity, had moderately high but non-significant values, probably as a result of the inclusion of the two riparian sites that were rich in liverworts, very moist and unburned.

Only time since fire explained significant variation in crustose lichen species turnover, while vascular plant cover explained most variation in foliose lichen species turnover. Time since logging, logging intensity and slope did not explain a significant amount of species turnover of any of the individual life-forms.

The first CCA axis mainly represented the difference between two of the riparian sites (which had many unusual bryophyte and lichen species) and the rest of the sites. These two sites remained unburned for at least 25 years longer than any of the others. When they were omitted from the analysis, the remaining sites were well separated in ordination space and their removal lowered the eigenvalues or amount explained by the environmental variables (bryophytes: axis $1=0.334$, axis $2=0.218$; lichens: axis $1=0.180$, axis $2=0.163$ ).
However, the amount of species turnover was little affected. Gradient length on DCA was only 0.3 less for bryophytes when the two sites were excluded, and was no different for lichens. There was only one less cluster at the 0.8 and 0.6 levels of dissimilarity for bryophytes when the two sites were removed.

Table 3. Canonical correspondence analysis results for bryophytes and lichens

\begin{tabular}{lllll}
\hline & \multicolumn{2}{c}{ Bryophytes } & \multicolumn{2}{c}{ Lichens } \\
& Individual & Model & Individual & Model \\
& & & & \\
Vascular plant cover & $6.0^{\star \star \star}$ & $4.0^{\star}$ & $4.8^{\star \star}$ & $4.2^{\star}$ \\
Time since last fire & $8.9^{\star \star \star}$ & $8.9^{\star \star \star}$ & $5.9^{\star \star}$ & $5.9^{\star \star}$ \\
Topographic position & $7.0^{\star \star \star}$ & & $4.0^{\star}$ & \\
Altitude & 3.6 & $3.6^{\star}$ & 4.0 & $4.0^{\star}$ \\
Aspect & 3.4 & & 3.1 & \\
Slope & 3.4 & & 3.5 & \\
Time since logging & 3.1 & & 3.1 & \\
Logging intensity ${ }^{\ddagger}$ & 3.4 & & 3.2 & \\
Fire intensity & & 2.1 & & 2.6 \\
\hline
\end{tabular}

†35 burnt sites only; ${ }^{\ddagger} 28$ logged sites only; ${ }^{\star} P<0.05$, ${ }^{\star \star} P<0.01,{ }^{\star \star \star} P<0.001$. Percentage variation in species data explained by environmental variables with each variable tested individually and then combined (model). Only variables that explain unique and significant variation are included in the model.

Table 2. Species turnover for bryophytes, lichens and their sub-groups.

\begin{tabular}{|c|c|c|c|c|c|c|}
\hline & \multicolumn{3}{|c|}{ Bryophyte ( 25 sites only) } & \multicolumn{3}{|c|}{ Lichen ( 35 sites only) } \\
\hline & All & Moss & Liverwort & All & Crustose & Foliose \\
\hline Gradient length & 3.39 & 2.84 & 4.42 & 2.23 & 2.41 & 3.85 \\
\hline \multicolumn{7}{|l|}{ No. clusters } \\
\hline 0.8 & 1 & 1 & 5 & 1 & 1 & 3 \\
\hline 0.7 & 4 & 3 & 8 & 2 & 2 & 6 \\
\hline 0.6 & 10 & 7 & 13 & 7 & 2 & 10 \\
\hline
\end{tabular}

Gradient length is the length of the first axis of detrended correspondence analysis. No. clusters indicates the number of groups formed at three levels of dissimilarity. Liverworts were only found in 25 sites and therefore species turnover for all three bryophyte groups was assessed across these sites only. Foliose lichens were absent from one site.

Table 4. Canonical correspondence analysis results for mosses and liverworts, and crustose and foliose lichens

\begin{tabular}{|c|c|c|c|c|c|c|c|c|}
\hline & $\begin{array}{r}\text { Mos } \\
\text { Individual }\end{array}$ & ss & $\begin{array}{r}\text { Liverw } \\
\text { Individual }\end{array}$ & Model & $\begin{array}{l}\text { Crustose } 1 \\
\text { Individual }\end{array}$ & $\begin{array}{l}\text { lichen } \\
\text { Model }\end{array}$ & $\begin{array}{l}\text { Foliose li } \\
\text { Individual }\end{array}$ & $\begin{array}{l}\text { ichen } \\
\text { Model }\end{array}$ \\
\hline Vascular plant cover & $5.4^{\star \star}$ & $3.9^{\star}$ & $8.3^{\star}$ & $8.3^{\star}$ & $5.7^{\star \star \star}$ & $5.7^{\star \star \star}$ & 4.0 & \\
\hline Time since fire & $8.4^{\star \star \star}$ & $8.4^{\star \star \star}$ & 9.7 & & 3.3 & & $5.6^{\star}$ & $5.6^{\star}$ \\
\hline Topographic position & $6.5^{\star \star}$ & & 8.0 & & 3.8 & & 3.1 & \\
\hline Altitude & 3.9 & $3.9^{\star}$ & 4.0 & & 3.8 & & 3.5 & \\
\hline Aspect & 3.5 & & 4.4 & & 2.9 & & 3.1 & \\
\hline Slope & 3.9 & & 2.6 & & 2.9 & & 3.8 & \\
\hline Time since logging & 3.5 & & 2.1 & & 2.4 & & 3.3 & \\
\hline Logging intensity ${ }^{\ddagger}$ & 2.7 & & 5.9 & & 5.2 & & 3.1 & \\
\hline Fire intensity ${ }^{\dagger}$ & 4.4 & & 8.0 & & 1.9 & & 2.3 & \\
\hline
\end{tabular}

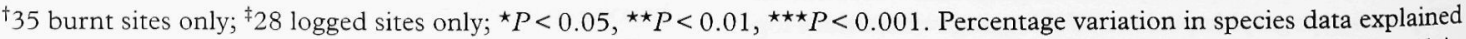
by environmental variables with each variable tested individually and then combined (model). Only variables that explain unique and significant variation are included in the model. 
Without two of the riparian sites, bryophyte species turnover was significantly associated with vascular plant cover only (percentage explained $=3.29, P=0.003$ ), although altitude was almost significant once the variation due to vascular plant cover was removed (percentage explained $=2.47, P=0.065$; Fig. 2 ). For lichens, vascular plant cover $(F=1.53, P=0.01)$, altitude $(F=1.49, P=0.02)$ and time since last fire $(F=1.39$, $P=0.04$ ) still explained a significant amount of species turnover, although time since last fire no longer explained the most variation.

Canonical correspondence analysis has been criticised for its inability to reveal unmeasured gradients because axes are restricted to linear combinations of those selected for measurement (Kantvilas \& Minchin 1989). To check for undetected variation in the species data, each environmental variable was fitted to the HMDS ordination using 'vector fitting' (using DECODA, Minchin 1991; Kantvilas \& Minchin 1989). The resulting configurations from the two ordination methods were fairly congruent and the same environmental variables explained significant variation in both. Correlations of environmental variables with HMDS axes revealed that the first two axes were accounted for in both bryophyte and lichen analyses but the third was not. In their study of epiphytic lichen communities in Tasmanian rainforest, Kantvilas and Minchin (1989) also found that variation along the third axis could not be explained by the measured environmental variables and postulated that it was a microclimatic gradient. The importance of the micro-environment in explaining the remaining variation in bryophyte and lichen diversity will be examined in a subsequent paper.

\section{DISCUSSION}

Bryophytes and lichens showed contrasting habitat preferences and their species richness was negatively correlated. Bryophytes were most diverse in moist habitats and lichens most diverse in dry ones. This pattern may reflect divergent reproductive and physiological requirements in the two groups. Bryophytes have an absolute requirement for free water for sexual reproduction and full photosynthetic activity (Sveinbjörnsson \& Oechel 1992; Scott 1994). Little is known about the reproduction of lichens except that it can occur in dry environments (Eldridge, pers. comm. 1996). Pigments and thickened cortex tissues adapt lichens to high light, dry habitats (Smith 1921; Hale 1967; Pritchard \& Bradt 1984).

Species turnover was greater for bryophytes than lichens but most of the bryophyte turnover was attributable to changes in liverwort species. Among the lichens, the foliose species showed greater turnover than the others. Crustose lichens in particular may have a far wider tolerance of environmental variation than bryophytes (Weber 1977). Although the spores of bryophytes and lichens are similar in size (Crum 1972; van Zanten \& Pocs 1981), wind dispersal of lichen propagules may be favoured in dry sclerophyll forests which support sparse understoreys, while dense ground vegetation may militate against the dispersal of bryophyte spores in moist forests. The greater levels of species turnover in the liverworts and foliose lichens may be the result of narrow habitat tolerances. Liverworts thrive in moist habitats and it was there that their diversity was highest (see also Barkman 1958; Gradstein et al. 1989; Kantvilas \& Jarman 1993). Adaptation to drier conditions may bring with it the constraint of narrower habitat tolerances leading to a greater turnover of species in space. A similar line of reasoning may apply to foliose lichens, with the critical factor being shade.

The patterns of both bryophyte and lichen diversity were associated with the same three correlated environmental variables: vascular plant cover, time since last fire and topographic position. These variables are important in the determination of the moisture and light status of the habitat and may explain the weak correlation between the species turnovers of the two groups. The importance of the disturbance variable, fire, was emphasized by the analyses. Further, it was clear that time since last fire was the crucial variable, rather than fire intensity. This is most likely to be because all the substrates sampled in this study were on or close to the ground, where there would be no escape for these organisms whatever the intensity of the fire.

Some logging methods appear to be consistent with the maintenance of bryophyte and lichen diversity as time since logging and logging intensity were not significant factors in any aspect of this study. Nieppola (1992) came much to the same conclusion following a study of selective logging of pine in southern Finland. However, generalizing from this result to other forests with different species mixes, in different climatic zones and on different soils would require many more similar studies. Further, the dominance of fire as the key factor in this study may be, at least in part, the result of its use in forest management. Of the other variables, altitude played a minor role in determining bryophyte and lichen diversity, although other studies that have included major elevational gradients have found that altitude is important (Slack 1977; Lee \& La Roi 1979; Wolf 1994). Unlike Söderström (1981) we found no effect of site aspect, and angle of slope also explained little variance.

The emergence of fire as a key variable affecting bryophyte and lichen diversity may be because it first kills these organisms and then determines, at least in part, the moisture regime of the habitat through the frequency and extent of the disruption of the vascular plant community, which is, in turn, related to topography. In the environments we studied, the valleys 
harboured moister habitats with multi-layered vegetation that burned less frequently than the upper slopes, which were drier and supported sparse understoreys. The distribution and abundance of bryophyte and lichen species was greatly affected by fire but not uniformly so. Patterns of both species richness and species turnover differed between the two major taxa and varied among the sub-groups.

Dissimilarities in the distribution of bryophyte and lichen biodiversity revealed by the methods used suggest that neither group appears to be a useful candidate as an indicator, or surrogate for the other, in conservation evaluation and planning. In more general terms, these 'lower plants' or cryptogams are too heterogeneous to be regarded as a single functional group for conservation purposes. Although both groups responded to the same habitat variables, the low correlation between their pair-wise site dissimilarities shows that they do so in different ways, a reminder that environmental variables alone are insufficient to predict patterns of diversity. Differences in habitat preferences for bryophytes and lichens, mediated by moisture levels, are well documented in the literature, and lead to the conclusion that conservation of these groups requires both moist and dry sites. However, the importance of overlying patterns of species turnover is less well recognized. Species-poor sites may harbour unique assemblages crucial to a comprehensive and adequate reserve system. Further, these sites may differ between the two groups in terms of both their frequency and their location. The rate of species turnover suggests that a larger number of these sites are required to achieve complementarity for liverworts and foliose lichens than for other sub-groups. On the other hand, the low correlation of pair-wise site dissimilarities does not necessarily mean that high conservation value sites will be different for bryophytes and lichens. Indeed, the riparian sites emerged as having unusual bryophyte and lichen assemblages. Minimum reserve set algorithms will be used in a subsequent paper to determine the overlap in reserve sites for the two groups.

\section{ACKNOWLEDGEMENTS}

We would like to thank Doug Binns, State Forests of NSW, for his support of the project; Brett Shields for generously providing field accommodation; Alan Archer, Alison Downing, Jack Elix, Gintaras Kantvilas, Pat McCarthy and Heinar Streimann for help with difficult specimens; and Michael Dunlop, Dan Faith, Rod Fensham, Janice Lord, Sue McIntyre, Ian Oliver, Rod Rogers and J. Bastow Wilson for their comments on the manuscript. This research was supported in part by an Australian Postgraduate Research Award (E.P.). This paper is submission number 220 of the Key Centre of Biodiversity and Bioresources.

\section{REFERENCES}

Barkman J. J. (1958) Phytosociology and Ecology of Cryptogamic Epiphytes. Van Gorcum Co., Assen, Netherlands.

Belbin L. (1991a) PATN: pattern analysis package. Users guide. CSIRO, Division of Wildlife and Ecology, Canberra.

Belbin L. (1991b) PATN: pattern analysis package. Technical reference manual. CSIRO, Division of Wildlife and Ecology, Canberra.

Binns D. L. (1996) Flora survey, Morisset Forestry District, Central Region, New South Wales. Morisset Forestry District EIS Support Document No. 3, Research Division, State Forests of NSW, Sydney.

Brodo I. M. (1973) Substrate ecology. In: The Lichens (eds V. Ahmadjian \& M. E. Hale) pp. 401-41. Academic Press, London.

Brown M. J., Jarman S. J. \& Kantvilas G. (1994) Conservation and reservation of non-vascular plants in Tasmania, with special reference to lichens. Biodiv. Conserv. 3, 263-78.

Crum H. (1972) The geographic origins of the mosses of North America's eastern deciduous forest. F. Hattori Bot. Lab. 35, 269-98.

Eilertsen O., Okland R. H., Okland T. \& Pedersen O. (1990) Data manipulation and gradient length estimation in DCA ordination. F. Veg. Sci. 1, 261-70.

Faith D. P., Minchin P. R. \& Belbin L. (1987) Compositional dissimilarity as a robust measure of ecological distance. Vegetatio 69, 57-68.

Forestry Commission of New South Wales (1984) Management plan for Wyong Management Area. Forestry Commission of New South Wales, Sydney.

Gradstein S. R., Van Reenen G. B. A. \& Griffin D. (1989) Species richness and origin of the bryophyte flora of the Colombian Andes. Acta Bot. Neerl. 38, 439-48.

Hale M. E. (1967) The Biology of Lichens. Edward Arnold Ltd, London.

Jarman S. J. \& Kantvilas G. (1994) Lichens and bryophytes of the Tasmanian World Heritage Area. II. Three forest sites at Pelion Plains. Tasforests 6, 103-20.

Jarman S. J. \& Kantvilas G. (1995) A floristic study of rainforest bryophytes and lichens in Tasmania's myrtle-beech alliance. Tasmanian National Rainforest Conservation Program Report No. 14. Forestry Tasmania, Hobart.

Jongman R. H. G., Ter Braak C. J. F. \& Van Tongeren O. F. R. (1995) Data Analysis in Community and Landscape Ecology, 2nd edn. Cambridge University Press, Cambridge, UK.

Kantvilas G. \& Jarman S. J. (1993) The cryptogamic flora of an isolated rainforest fragment in Tasmania. Bot. F. Linn. Soc. 111, 211-28.

Kantvilas G. \& Minchin P. R. (1989) An analysis of epiphytic lichen communities in Tasmanian cool temperature rainforest. Vegetatio 84, 99-112.

Lee T. D. \& La Roi G. H. (1979) Bryophyte and understorey vascular plant beta diversity in relation to moisture and elevation gradients. Vegetatio 40, 29-38.

McCarthy P. M. (1991) Checklist of Australian Lichens, 4th edn. National Herbarium of Victoria, Melbourne.

Minchin P. R. (1991) DECODA: database for ecological community data. Anutech, Australian National University, Canberra.

Nagano I. (1969) Comparative studies of moss vegetation developing on limestone, chert, and other rocks lying adjacent to each other in the Chichibu Mountain area, central Japan. f. Hattori Bot. Lab. 32, 155-203.

Nieppola J. (1992) Long-term vegetation changes in stands of Pinus sylvestris in southern Finland. 7. Veg. Sci. 3, 475-84. 
Pritchard H. N. \& Bradt P. T. (1984) Biology of Nonvascular Plants. Times Mirror/Mosby College Publishing, New York. Scott G. A. M. (1994) Elementary reflections on the biology of bryophytes. Vic. Nat. 111, 112-15.

Scott G. A. M. \& Bradshaw J. A. (1986) Australian liverworts (Hepaticae). Brunonia 8, 1-171.

Slack N. G. (1977) Species diversity and community structure in bryophytes: New York State studies. Bull. NY State Mus. 428, $1-70$.

Smith A. L. (1921) Lichens. Cambridge University Press, Cambridge, UK.

Söderström L. (1981) Distribution of bryophytes in spruce forests on hill slopes in central Sweden. Wahlenbergia 7, 141-53.

Söderström L. (1993) Substrate preference in some forest bryophytes: a quantitative study. Lindbergia 18, 98-103.

Sokal R. R. \& Rohlf F. J. (1995) Biometry: The Principles and Practice of Statistics in Biological Research, 3rd edn. W. H. Freeman and Company, New York.

SPSS for Windows (1993) Release 6. SPSS Inc., Chicago, Illinois.

Stark L. R. \& Castetter R. C. (1987) A gradient analysis of bryophyte populations in a desert mountain range. NY Bot. Gardens Mem. 45, 186-97.

State Forests of New South Wales (1995) Morisset Forestry District Environmental Impact Statement. State Forests of New South Wales, Sydney.

Streimann H. \& Curnow J. (1989) Catalogue of Mosses of
Australia and Its External Territories. Australian Flora and Fauna Series 10. Australian Government Publishing Service Press, Canberra.

Sveinbjörnsson B. \& Oechel W. C. (1992) Controls on the growth and productivity of bryophytes: environmental limitations under current and anticipated conditions. In: Bryophytes and Lichens in a Changing Environment (eds J. W. Bates \& A. M. Farmer) pp. 77-102. Oxford University Press, New York.

ter Braak C. J. F. (1991) CANOCO - a FORTRAN program for Canonical Community Ordination. Microcomputer Power, Ithaca, New York.

ter Braak C. J. F. \& Prentice I. C. (1988) A theory of gradient analysis. Adv. Ecol. Res. 18, 271-317.

van Zanten B. O. \& Pocs T. (1981) Distribution and dispersal of bryophytes. Adv. Bryol. 1, 479-562.

Vitt D. H., Li Y. \& Belland R. J. (1995) Patterns of bryophyte diversity in peatlands of continental Western Canada. The Bryologist 98, 218-27.

Weber W. A. (1977) Environmental modification and lichen taxonomy. In: Lichen Ecology (ed. M. R. D. Seaward) pp. 9-29. Academic Press, London.

Whittaker R. H. (1977) Evolution of species diversity in land communities. Evol. Biol. 10, 1-67.

Wolf J. H. D. (1994) Factors controlling the distribution of vascular and non-vascular epiphytes in the northern Andes. Vegetatio 112, 15-28.

APPENDIX I. Presence of species in vascular plant cover categories. Percentage cover of vascular plants was calculated by summing the percentage cover of all plants within each of four strata (1-6 m, 6.1-20 m, 20.1-35 m, over $35 \mathrm{~m}$ )

\begin{tabular}{|c|c|c|c|c|c|c|}
\hline & $n$ & $\begin{array}{c}1 \\
28-60 \\
8\end{array}$ & $\begin{array}{c}2 \\
61-66 \\
7\end{array}$ & $\begin{array}{c}3 \\
67-78 \\
7\end{array}$ & $\begin{array}{c}4 \\
79-105 \\
7\end{array}$ & $\begin{array}{c}5 \\
106+ \\
7\end{array}$ \\
\hline \multicolumn{7}{|l|}{ Bryophytes } \\
\hline \multicolumn{6}{|l|}{ Anthocerotae (hornworts) } & $\star$ \\
\hline \multicolumn{7}{|l|}{ Hepaticae (liverworts) } \\
\hline Acrolejeunea securifolia & & & & & & $\star$ \\
\hline Acromastigum exiguatum & & & & & $\star$ & \\
\hline Bazzania involuta & & * & & & * & $\star$ \\
\hline Cheilolejeunea mimosa & & & & & & $\star$ \\
\hline Chiloscyphus argutus & & & & & $\star$ & $\star$ \\
\hline Chiloscyphus semiteres & & $\star$ & & $\star$ & * & * \\
\hline Frullania monocera & & & & $\star$ & $\star$ & $\star$ \\
\hline Frullania probosciphora & & * & & & & \\
\hline Frullania squarrulosa & & * & $\star$ & $\star$ & $\star$ & \\
\hline Goebelobryum unguiculatum & & & & & & $\star$ \\
\hline Lejeunea drummondii & & & & & $\star$ & $\star$ \\
\hline Lejeunea primordialis & & & & & $\star$ & $\star$ \\
\hline Lepidoziaceae spp. & & $\star$ & & & $\star$ & * \\
\hline Lethocolea squamata & & $\star$ & & & & \\
\hline Metzgeria decipiens & & & & & * & $\star$ \\
\hline Podomitrium phyllanthus & & & & & & * \\
\hline Telaranea centipes & & * & & & & \\
\hline Telaranea dispar & & * & & & $\star$ & $\star$ \\
\hline Trichocolea mollissima & & & & & & $\star$ \\
\hline Zoopsis argentea & & & & & & * \\
\hline \multicolumn{7}{|l|}{ Musci (mosses) } \\
\hline Acrophyllum dentatum & & & & & & $\star$ \\
\hline Barbula australasiae & & & $\star$ & & & \\
\hline Barbula calycina & & & & & & * \\
\hline Barbula sp. A & & & & & $\star$ & \\
\hline Brachythecium rutabulum & & & & & & * \\
\hline Bryum billardieri & & $\star$ & 夫 & * & $\star$ & * \\
\hline Bryum crassum & & $\star$ & & & & \\
\hline
\end{tabular}


APPENDIX I. (continued)

$\begin{array}{cccccc} & 1 & 2 & 3 & 4 & 5 \\ & 28-60 & 61-66 & 67-78 & 79-105 & 106+ \\ n & 8 & 7 & 7 & 7 & 7\end{array}$

Bryum rubens

Bryum sp. A

Camptochaete arbuscula

Campylopus introflexus

Campylopus pyriformis

Cephaloziella exiliflora

Ceratodon purpureus

Cryphaea dilitata

Cryphaea exannulata

Dicnemoloma pallidum

Dicranoloma menziesii

Distichophyllum crispulum

Ditrichum difficile

Eucamptodon muelleri

Fissidens asplenioides

Fissidens humilis

Fissidens oblongifolius

Fissidens pallidus

Fissidens pungens

Fissidens spp.

Fissidens subhumilis

Fissidens taylorii

Fissidens tenellus

Grimmia pulvinata

Hypnodendron vitiense

Hypnum cuppressiforme

Hypopterygium rotulatum

Isopterygium limatum

Leucobryum candidum

Macromitrium archeri

Mesochaete undulata

Orthodontium lineare

Orthotrichum assimile

Papillaria crocea

Pterygophyllum dentatum

Pyrrhobryum mnoides

Pyrrhobryum parramattense

Racopilum cuspidigerum var. cuspidigerum

Rhynchostegium tenifolium

Sematophyllum amoenum

Sematophyllum contiguum

Syrrhopodon armatus

Thamnobryum sp. A

Thuidium sparsum var. sparsum

Tortula muralis

Weissia controversa

Weissia rutilans

Wijkea extenuata

Zygodon intermedius

\section{*}

\section{Lichens}

Crustose

Bacidia spp.

Buellia sp. A

Buellia stellulata

Byssoloma leucoblepharum

Byssoloma subdiscoidans

Chaenotheca spp. 
APPENDIX I. (continued)

\begin{tabular}{|c|c|c|c|c|c|c|}
\hline & $n$ & $\begin{array}{c}1 \\
28-60 \\
8\end{array}$ & $\begin{array}{c}2 \\
61-66 \\
7\end{array}$ & $\begin{array}{c}3 \\
67-78 \\
7\end{array}$ & $\begin{array}{c}4 \\
79-105 \\
7\end{array}$ & $\begin{array}{c}5 \\
106+ \\
7\end{array}$ \\
\hline Chrysothrix candelaris & & * & * & * & $\star$ & $\star$ \\
\hline Graphis spp. & & 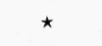 & * & * & * & * \\
\hline Lecanora campestris gp. & & * & * & $\star$ & * & $\star$ \\
\hline Lecanora varia gp. & & * & * & * & * & $\star$ \\
\hline Lecanoraceae spp. & & $\star$ & $\star$ & * & * & * \\
\hline Lepraria incana & & * & * & $\star$ & * & * \\
\hline Megalaria sp. A & & * & * & * & & * \\
\hline Neophyllis melacarpa & & * & & & & \\
\hline Pachyphiale cornea & & * & & & * & * \\
\hline $\begin{array}{l}\text { Pertusaria cf. lacerans } \\
\text { Proriarion }\end{array}$ & & & & & & * \\
\hline $\begin{array}{l}\text { Pertusaria elliptica var. nov. bispora } \\
\text { Pertusaria gibberosa }\end{array}$ & & * & & & $\star$ & \\
\hline $\begin{array}{l}\text { Pertusaria gibberosa } \\
\text { Pertusaria leucoplaca }\end{array}$ & & * & & & $\star$ & \\
\hline $\begin{array}{l}\text { Pertusaria leucoplaca } \\
\text { Pertusaria novazelandiae }\end{array}$ & & * & * & & & \\
\hline $\begin{array}{l}\text { Pertusaria novazelandiae } \\
\text { Pertusaria persulfurata }\end{array}$ & & * & 夫 & $\star$ & * & \\
\hline Pertusaria scaberula & & * & * & * & * & \\
\hline Pertusaria schizostomella & & & * & & & \\
\hline Pertusaria subventosa & & & $\star$ & * & & \\
\hline Pertusaria thiospoda & & * & & & & $\star$ \\
\hline Pertusaria thwaitsii & & $\star$ & $\star$ & * & & 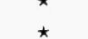 \\
\hline Porpidia spp. & & $\star$ & $\star$ & ᄎ & & ^ \\
\hline Psilolechia spp. & & 夫 & * & $\star$ & $\star$ & $\star$ \\
\hline $\begin{array}{l}\text { Unknown sp. A } \\
\text { Unknown sp. B }\end{array}$ & & & * & * & $x$ & x \\
\hline \multirow{2}{*}{\multicolumn{7}{|c|}{ Foliose }} \\
\hline & & & & & & \\
\hline Cladonia cervicornis ssp. verticillata & & * & & * & $\star$ & \\
\hline $\begin{array}{l}\text { Cladonia } \text { cf. subsquamata } \\
\text { Cladonia corniculata }\end{array}$ & & & & * & ^ & \\
\hline $\begin{array}{l}\text { Cladonia corniculata } \\
\text { Cladonia floekeana }\end{array}$ & & & & & * & \\
\hline $\begin{array}{l}\text { Cladonia floekeana } \\
\text { Cladonia macilenta }\end{array}$ & & * & & * & & \\
\hline $\begin{array}{l}\text { Cladonia macilenta } \\
\text { Cladonia ochrochlora }\end{array}$ & & * & & & & \\
\hline $\begin{array}{l}\text { Cladonia ochrochlora } \\
\text { Cladonia praetermissa }\end{array}$ & & & $\star$ & & & \\
\hline $\begin{array}{l}\text { Cladonia praetermissa } \\
\text { Cladonia ramulosa }\end{array}$ & & * & * & & * & \\
\hline $\begin{array}{l}\text { Cladonia ramulosa } \\
\text { Cladonia rigida }\end{array}$ & & $\star$ & * & * & * & * \\
\hline $\begin{array}{l}\text { Cladonia rigida } \\
\text { Cladonia spp. }\end{array}$ & & * & * & * & * & $\star$ \\
\hline $\begin{array}{l}\text { Cladonia spp. } \\
\text { Flavoparmelia euplecta }\end{array}$ & & * & & * & * & * \\
\hline $\begin{array}{l}\text { Flavoparmelia euplecta } \\
\text { Flavoparmelia rutidota }\end{array}$ & & & & & 夫 & \\
\hline $\begin{array}{l}\text { Flavoparmelia rutidota } \\
\text { Heterodermia obscurata }\end{array}$ & & & & * & $\star$ & \\
\hline $\begin{array}{l}\text { Heterodermia obscurata } \\
\text { Heterodermia pseudospecrosa }\end{array}$ & & & & * & & $\star$ \\
\hline $\begin{array}{l}\text { Heterodermia pseudospecrosa } \\
\text { Heterodermia sp. A }\end{array}$ & & & & & * & * \\
\hline $\begin{array}{l}\text { Heterodermia sp. A } \\
\text { Hypocenomyce } \text { cf. scalaris }\end{array}$ & & * & & & & \\
\hline $\begin{array}{l}\text { Hypocenomyce cf. scalaris } \\
\text { Hypogymnia billardieri }\end{array}$ & & $\star$ & * & * & $\star$ & * \\
\hline $\begin{array}{l}\text { Hypogymnia billardieri } \\
\text { Hypogymnia subphysodes }\end{array}$ & & * & $\star$ & $\star$ & * & \\
\hline $\begin{array}{l}\text { Hypogymnia subphysodes } \\
\text { Hypotrachyna booralensis }\end{array}$ & & * & * & $\star$ & & \\
\hline $\begin{array}{l}\text { Hypotrachyna booralensis } \\
\text { Hypotrachyna immaculata }\end{array}$ & & $\star$ & * & * & * & * \\
\hline $\begin{array}{l}\text { Hypotrachyna immaculata } \\
\text { Hypotrachyna osseoalba }\end{array}$ & & * & * & * & * & \\
\hline $\begin{array}{l}\text { Hypotrachyna osseoalba } \\
\text { Hypotrachyna sp. A }\end{array}$ & & * & & & n & \\
\hline $\begin{array}{l}\text { Hypotrachyna sp. A } \\
\text { Leiodermia duplicatum }\end{array}$ & & & & & $\star$ & \\
\hline $\begin{array}{l}\text { Leiodermia duplicatum } \\
\text { Leptogium rogersii }\end{array}$ & & & & & & $\star$ \\
\hline $\begin{array}{l}\text { Leptogium rogersii } \\
\text { Pannoparmelia wilsonii }\end{array}$ & & * & * & * & * & \\
\hline & & & & * & & \\
\hline $\begin{array}{l}\text { Parmelia erumpens } \\
\text { Parmelia immaculata }\end{array}$ & & * & * & * & * & * \\
\hline Parmelina conlabrosa & & * & * & * & * & 夫 \\
\hline Parmelinopsis horrescens & & $\star$ & & $\star$ & & * \\
\hline Parmelinopsis minarum & & * & * & * & * & \\
\hline Parmotrema mellissii & & * & * & ^ & * & ^ \\
\hline Pseudocyphellaria dissimilis & & & & & $\star$ & $x$ \\
\hline Punctelia subrudecta & & & & & & \\
\hline
\end{tabular}


APPENDIX I. (continued)

$\begin{array}{cccccc}1 & 2 & 3 & 4 & 5 \\ 28-60 & 61-66 & 67-78 & 79-105 & 106+ \\ 8 & 7 & 7 & 7 & 7 \\ \star & \star & \star & \star & & \\ & \star & \star & & & \\ & \star & \star & \star & & \\ \star & \star & \star & \star & \star \\ & \star & \star & & \star \\ & \star & \star & & \star\end{array}$

^Indicates species found at sites within the range specified. 
This document is a scanned copy of a printed document. No warranty is given about the accuracy of the copy. Users should refer to the original published version of the material. 